\title{
KONSEP JUAL BELI DALAM FATWA DSN-MUI
}

\author{
Nur Fathoni, IAIN Walisongo Semarang
}

\begin{abstract}
There are several fatwas issued about buying and selling is not sequentially and respectively describes their own subject matter. As a result of modern Islamic legal thought, DSN MUI fatwa interesting to study inductively to find a linkage study of classical fiqh with the provisions of the banking system and mechanism in these fatwas. The problems studied in this paper is the concept of buying and selling in the DSN - MUI fatwa is How it relates to the system of figh and Shari'ah banking mechanism in DSN - MUI fatwa?. This study is the research literature by using a qualitative approach.

The study found a link between the data and the system of fiqh with the provisions of Shari'ah banking mechanism DSN - MUI fatwa about buying and selling. The concept of buying and selling in the DSN - MUI fatwa designed to avoid gharar, riba by changing procedures and financing dhalim be based iwadh item form, not a loan ( qardh), set the selling price as the final price that can not be combined with any cause, but can reduced on the basis of LKS policy. Late fee of rich clie not being able to shariah bank. In buying and selling foreign exchange should require cash, as opposed to buying and selling goods that is designed to delay installments. The results of the Islamic legal thought DSN - MUI fatwa about buying and selling successfully avoid formalistic forms of riba, gharar and dhalim, but have not managed to uphold the moral essence in buying and selling. Morality and law are still separate in their each areas.
\end{abstract}

Kata kunci: Fatwa, DSN-MUI, Jual-beli, prinsip-prinsip bukum Islam.

\section{Pendahuluan}

Jual beli adalah salah satu cara perpindahan kepemilikan yang dihalalkan oleh al-Qur'an. Ia telah ada sebelum al-Qur'an diturunkan. alQur'an mengatur tijarah (bisnis) yang didalamnya termasuk jual beli, agar pelaksanaannya dilakukan atas dasar saling rela ${ }^{1}$ (Departemen Agama RI, 1989:

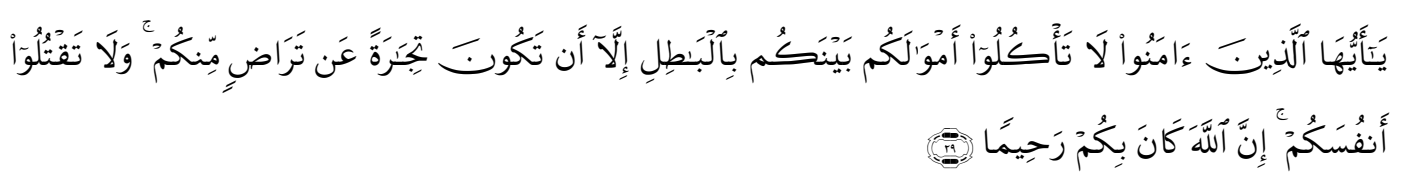

Volume IV/Edisi 1/Mei 2013 
Konsep Jual Beli dalam Fatwa DSN-MUI

122)2. al-Qur'an menggambarkan kekeliruan pandangan kaum jabiliyah yang menyamakan jual beli dengan riba. Jual beli ditegaskan oleh al-Qur'an sebagai lawan riba. Jual beli dinyatakan halal sedangkan riba dinyatakan haram (Q.S.2:275)33 (Departemenpa Agama RI, 1989: 69).

Nabi Muhammad menyebut jual beli mabrur sebagai salah satu usaha yang baik 4 . Ada hal penting yang harus diperhatikan dalam praktik jual beli. Khalifah Umar bin Khatab, sebagaimana dikutip oleh Sayyid Sabiq pernah mengingatkan kepada para pedagang agar mengetahui tata cara jual beli yang benar, agar tidak terjerumus pada praktik riba ${ }^{5}$. Riba dalam jual beli adalah rambu-rambu yang sering diingatkan oleh Nabi. Dalam beberapa hadits, Nabi menyebutkan ada barang-barang yang hanya boleh ditukar (dijual belikan) atas dasar kesamaan timbangan atau takaran dan kontan. Jika tidak demikian maka praktik pertukaran tersebut adalah mengandung riba $a^{6}$ Nabi menyebut beberapa nama jual beli yang dilarang karena riba, menipu atau tidak jelas akibat transaksinya (gharar). Hal ini menunjukkan bahwa riba dan perbuatan terlarang lainnya bisa terjadi pada praktik jual beli, meskipun al-Qur'an menempatkan keduanya pada dua kutub yang berlawanan dengan menghalalkan jual beli dan mengharamkan riba.

Tuntunan yang dikemukakan al-Qur'an dan Hadits memiliki latar belakang masyarakat Arab abad ke-7M7 , termasuk di dalamnya kegiatan bisnis dan perniagaan. Pada masa itu model jual belinya banyak menggunakan cara barter, alat tukarnya menggunakan uang emas dan perak, belum dikenal lembaga keuangan sebagaimana pengertian modern. Meskipun al-Qur'an dan

\footnotetext{
2 Departemen Agama RI, 1989, Al-Qur'an Dan Terjemahnya, Semarang, CV.Toha Putra. Hal. 122

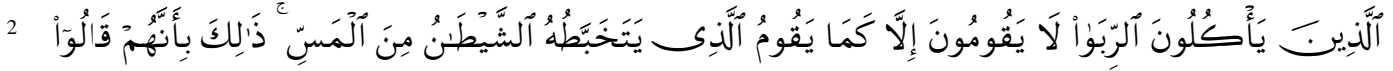

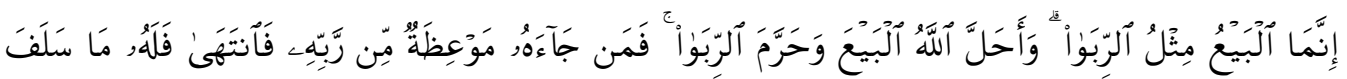

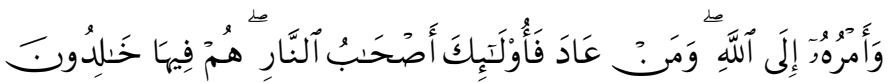

4 al-Asqalani, t.th, al-Hafidz Ibnu Hajar, Bulugh al-Maram Min Adillati al-Abkam, Semarang, Maktabah Usaha Keluarga. h.158

${ }^{5}$ Sabiq, Sayyid, 2000, Figh al-Sunnah, Dar al-Fatih. H.88

${ }^{6}$ al-Bukhari, Imam Abi Abdillah Muhammad Ibnu Isma'il Ibnu Ibrahim Ibnu al-Mughirah Ibnu Bardazabat, t.th, Al-Bukhari Masykul Bi Hasyizah al-Sanad, Juz. 2, Beirut, Dar al-Fikr. H.16-21

${ }^{7}$ Shihab, Quraish, 1993, Membumikan Al-Qur'an, Bandung, Mizan. H.89
} 
Hadits memiliki latar belakang sosial, kandungan al-Qur'an dan Hadits menjadi tuntunan umat manusia sepanjang zaman.

Dalam konsep ulama' fiqh, jual beli dikemas dalam kerangka formalistik hukum. Sisi dhabir nampak lebih dominan dibandingkan sisi bathin. Jual beli dikemas menjadi akad. Jual beli dirumuskan dalam tatanan syarat, rukun, syah, batal, hak dan kewajiban. Ada model jual beli yang dilarang dan ada jual beli yang diperkenankan. Konsep jual beli dalam fiqh merujuk kepada nash (al-Qur'an dan Hadits) dan menerima adat (dinamika) masyarakat. Ada akad musammah, yaitu transaksi yang telah ada namanya terutama terjadi pada masa Nabi dan akad ghairu musammah, yaitu akad yang belum ada namanya karena termasuk fenomena atau kebutuhan baru.

Akad jual beli pada masa modern dipakai juga untuk akad pembiayaan di bank syari'ah'. Bank Syari'ah adalah lembaga keuangan syariah yang menggunakan prinsip-prinsip syari'ah dalam kegiatannya. Ia didesain untuk menghindari riba. Ia memiliki fungsi sebagai lembaga keuangan yaitu, menerima uang dari masyarakat dan menyalurkan uang kepada masyarakat, melalui produk penghimpunan dana, penyaluran dana dan produk jasa yang disediakan bank syari'ah ${ }^{10}$. Pada konteks jual beli di bank syari'ah, nasabah penerima fasilitas pembiayaan menjadi pembeli barang dan bank syari'ah sebagai penjual barang dengan mekanisme perbankan sebagaimana lazimnya, diantaranya pembayaran model cicilan/angsuran. Keuntungan bank syari'ah dalam jual beli tersebut bisa dinyatakan dalam bentuk prosentase atas harga pokok barang. ${ }^{11}$. Ada dua kubu pemikiran tentang penerapan prinsip syari'ah pada bank syari'ah. Pertama, mendukung dan yakin dengan didukung

\footnotetext{
8 Tsalabi, Muhammad Mustofa, 1964, al-Madkhal Fi Ta'rif al-Figh al-Islam Wa Qawa'id alMilkiyyah Wa al-Uqudiyyah, Mathba'ah Dar al-Ta'rif. H.508

9 Antonio, Muhammad Syafi'i, 1999, Bank Syari'ab Wacana Ulama' dan Cendekia, Copyright@muhammad Syafi'i Antonio. H.127

${ }^{10}$ Ibid, Antonio, h249

${ }^{11}$ Karim, Adiwarman, 2004, Bank Islam Analisis Figh dan Kenangan, Jakarta, PT Raja Grafindo Persada. H.110
} 
argumentasi bahwa bank syari'ah mampu menghindari riba ${ }^{12}$. Kubu kedua, menganggap bank syari'ah gagal menghindari larangan riba ${ }^{13}$.

Ada problem hukum dalam teknis pelaksanaan jual beli di bank syari'ah. 1. Bank syari'ah yang didesain untuk hanya mengeluarkan uang, bukan barang harus berfungsi sebagai penjual barang. Bagaimana jual beli didesain/ditata. 2. Bank syari'ah didesain sebagai lembaga bisnis yang menghasilkan keuntungan dari setiap aktifitas bisnisnya, dan ia dibatasi oleh beberapa hukum dan etika sesuai prinsip-prinsip hukum Islam yaitu larangan riba, gharar, maisir, dhalim dan menjual barang haram. Bagaimana cara bank syari'ah menarik keuntungan yang dibenarkan syari’at Islam. 3. Teknis pengembalian pembiayaan di bank syari'ah menggunakan cara pembayaran tunda dan cicilan. Bagaimana hal itu disesuaikan dengan prinsip-prinsip hukum Islam. 4. Dalam hal jual beli secara tunda dan cicilan, muncul persoalan dengan batas waktu pembayaran dan besarnya pembayaran. Adakah kaitan antara besarnya kewajiban pembayaran dengan lamanya waktu yang disediakan bank syari'ah. Apa saja yang boleh dimasukkan sebagai unsur pendapatan bank syari'ah dalam melakukan jual beli dengan nasabah.

Menurut penulis, problematika di atas adalah problem konseptual yang membutuhkan kepastian hukum Islam tentang praktek jual beli di bank Syari'ah. Hukum Islam yang digunakan sebagai dasar kegiatan bank syari'ah diambil dari fatwa Dewan Syari'ah Nasional Majelis Ulama' Indonesia (DSNMUI) ${ }^{14}$.

Fatwa adalah salah satu produk pemikiran hukum Islam. Menurut Atho' Mudzhar ada dua pihak yang senantiasa aktif melaksanakan tugas pengembangan dan penerapan hukum Islam (ijtihad) yaitu para mufti (pemberi fatwa) dan qadli (hakim). Fatwa memiliki kekuatan hukum mengikat para

\footnotetext{
12 Consulting, Karim Busines, 2001, Islam Dan PerbankanSyariah, Jakarta, Biro Perbankan Syari'ah Bank Indonesia. H.11

13 Saeed, Abdullah, 2003, Islamic Banking And interest A Studi of Riba And Its Contemporary Interpretation, terj. Muhammad Ufuqul Mubin dkk, Bank Islam Dan Bunga, Yogyakarta, Pustaka Pelajar. H.145 H.18

14 Keputusan Dewan Syari’ah Nasional Majelis Ulama' Indonesia Nomor 1 Tahun 2001.
} 
penerima fatwa, sedangkan keputusan hakim mengikat para pihak yang diputus ${ }^{15}$.

Fatwa DSN-MUI muncul sebagai respon atas persoalan kekinian tentang ekonomi Islam, terutama yang berkaitan dengan Lembaga keuangan syari'ah, khususnya perbankan syari'ah, mengingat sebagian besar fatwa yang dikeluarkan berkaitan dengan persoalan sistem syari'ah pada perbankan syari'ah. Fatwa DSN-MUI menjadi rujukan bagi Bank Indonesia untuk membuat Peraturan Bank Indonesia (PBI) dan Dewan Pengawas Syari'ah (DPS) yang ada di masing-masing Lembaga Keuangan Syari'ah ${ }^{16}$.

Fatwa DSN-MUI telah ada sejak tahun 2000 dan selalu bertambah sesuai dengan persoalan kekinian yang muncul. Fatwa tersebut telah dibukukan pada tahun 2006. Dalam buku tersebut ada 53 fatwa. Belum ada edisi yang lebih baru lagi. Fatwa DSN-MUI terbaru bisa diunduh melalui website MUI. Sampai dengan tahun 2008 telah ada 75 fatwa DSN-MUI. Fatwa yang dikhususkan untuk perbankan syari'ah lebih banyak dibandingkan fatwa yang dikhususkan untuk lembaga keuangan lainnya. Fatwa yang paling banyak adalah fatwa umum, artinya tidak dikhususkan untuk lembaga keuangan tertentu.

Fatwa tentang teknis jual beli di perbankan syari'ah (terutama murabahah) adalah fatwa paling lengkap dan variatif dibanding fatwa tentang akad lainnya. Fatwa tentang akad jual beli paling lengkap karena mencakup berbagai hal tentang pelaksanaan jual beli yang meliputi prosedur jual beli yang dipakai, jenis-jenis/model-model jual beli yang bisa dilakukan, uang muka dalam jual beli, agunan/jaminan dalam akad jual beli, potongan harga dalam pelunasan jual beli, denda, penjadwalan ulang angsuran jual beli. Fatwa jual beli paling variatif karena ia bisa dilakukan sebagai akad munfarid (berdiri sendiri) maupun multi akad (bergabung dengan akad lain dalam satu transaksi) seperti transaksi ijarah muntabiyyah bi al-tamlik).

Fatwa-fatwa DSN-MUI tentang jual beli tidak berurutan munculnya dan masing-masing fatwa hanya membahas satu persoalan saja. Satu fatwa menjawab satu bagian persoalan jual beli di lembaga keuangan syari'ah. Satu

15 Mudzhar, Atho', 1993 Fatwa-Fatwa Majelis Ulama' Indonesia, Jakarta, INIS XVII. H. 1-2

16 Undang-Undang Nomor 21 Tahun 1998 tentang Perbankan Syari'ah. H.1-3 
Konsep Jual Beli dalam Fatwa DSN-MUI

fatwa memiliki keterkaitan dengan fatwa lainnya karena memutuskan persoalan dalam jenis akad yang sama. Keberadaan fatwa yang banyak dan berpencar menarik penulis untuk mengkaji secara induktif untuk mendapatkan kesimpulan tentang konsep jual beli modern. Permasalahan yang timbul dari latar belakang di atas adalah, bagaimana konsep jual beli dalam fatwa DSN-MUI, keterkaitan prinsip-prinsip hukum Islam dengan mekanisme perbankan.

\section{Rumusan Masalah}

Berdasarkan latar belakang masalah di atas, makalah ini dibatasi dalam satu rumusan masalah, yaitu: Bagaimana keterkaitan antara prinsip-prinsip hukum Islam berupa riba, gharar, maisir, dhalim dengan mekanisme perbankan syari'ah tentang jual beli, dalam fatwa DSN-MUI periode 2000-2008?. Apakah keterkaitannya formalistik atau substantif?

\section{Jual Beli Dalam Kajian Fiqh.}

\section{Definisi Jual Beli Dan Kaidah Umum Jual Beli}

Jual beli dalam istilah teknis fiqh menggunakan kata bai'. Kata tersebut sama dengan kata yang digunakan oleh al-Qur'an dan Hadits. Jual beli memiliki makna bahasa memberikan sesuatu sebagai bandingan sesuatu ${ }^{17}$. Kata bai' dan syira' adalah dua kata yang artinya berlawanan, namun sering dipertukarkan maknanya dalam al-Qur'an dan Hadits, kadang kata bai' digunakan untuk makna syira', dan kata syira' digunakan untuk makna bai ${ }^{18}$. Arti kata bai' dan syira' menurut bahasa adalah pertukaran secara mutlak, baik berupa harta maupun bukan harta ${ }^{19}$. Menurut makna istilah, jual beli didefinisikan berfariasi penekanannya. Jual beli menurut Taqiyuddin adalah pertukaran harta dengan harta untuk tujuan pemanfaatan menggunakan cara ijab Kabul sesuai dengan tuntunan yang diperkenankan syara $^{20}$. Jual beli

${ }^{17}$ al-Dimasyqi, Imam Taqiyuddin Abu Bakar Bin Muhammad al-Hasini al-Hashni, t.th., Kifayah al-Ahyar Fi Halli ghayah al-Ikhtishar, Dar Ikhya' al-Kutub al-Arabiyyah. H.239

${ }^{18}$ Musa, Kamil, t.th., Al-Abkam al-Mu'amalah, Mu'assasah al-Risalah. H. 133-234

${ }^{19}$ Ibid, Musa, h. 234

20 Al-Dimasyqi, Loc Cit, h.239 
menurut Sayyid Sabiq adalah pertukaran harta dengan harta atas dasar kerelaan. Pertukaran harta dimaksudkan sebagai perpindahan kepemilikan dengan penggantian menurut cara yang diperkenankan syara ${ }^{21}$. Kamil Musa mengutip pendapat Madzhab Hanafiyah yang sama dengan definisi yang dikemukakan Sayyid Sabiq22.

Definisi jual beli yang mencantumkan "atas dasar kerelaan" menempatkan kerelaan sebagai hal penting menurut syara'. Jual beli tanpa kerelaan menjadikan akad jual beli cacat. Kerelaan dalam jual beli kadang kala ada, kadang kala tidak ada. Ketika seseorang berkata, "saya jual" atau "saya beli", hal itu berarti pertanda (imarah) kerelaan, bukan illat adanya kerelaan. Menurut Kamil Musa hakekat kerelaan bukan bagian pemahaman jual beli menurut syara', tetapi syarat adanya hukum jual beli menurut syara ${ }^{23}$. Menurut Ibnu Abidin manakala kerelaan adalah bagian pemahaman jual beli menurut syara' maka jual beli yang terpaksa pasti batal, padahal jual beli tersebut adalah fasid, artinya jual beli terjadi walaupun fasid, oleh karenanya keberadaan jual beli tidak tergantung pada kerelaan ${ }^{24}$.

Definisi jual beli menurut syara' senada dengan definisinya menurut bahasa yaitu pertukaran harta dengan harta. Fiqh mengatur tatacara pelaksanaannya agar sesuai dengan syari'at Islam. Aturan syara' tersebut berupa ijab Kabul dan syarat rukun jual beli, disamping keberadaan kerelaan yang menjiwai ijab Kabul.

Rukun akad jual beli ada tiga. 1. Kedua belah pihak yang berakad memiliki kecakapan yaitu orang yang berakal dan baligh. 2. Barang yang dijual belikan adalah barang yang boleh dijual belikan. 3. Ada wasilah yang diperkenankan oleh syara' dan wujud dalam akad seperti sighat berupa perkataan atau tulisan, termasuk wasilah saling memberi diantara kedua belah pihak $^{25}$. Syarat syah, yaitu sesuatu yang menjadi penentu adanya sesuatu, tetapi ia tidak termasuk di dalam sesuatu tersebut. Sedangkan rukun adalah sesuatu yang menjadi penentu adanya sesuatu dan ia adalah bagian dari sesuatu

${ }^{21}$ Sabiq, Sayyid, 2000, Fiqh al-Sunnah, Dar al-Fatih. H. 90

22 Musa, Loc Cit, h. 234

${ }^{23}$ Ibid, Musa, h.235

24 Abidin, Ibnu, t.th, Radd al-Mukbtar, Juz. 4, Dar al-Fikr. H.3

${ }^{25}$ Musa, Op cit, h. 240 
tersebut. Manakala tidak terpenuhi syarat syah, jual beli masuk katagori fasad, sedangkan manakala tidak terpenuhi rukun jual beli menjadi batal.

Syarat syah jual beli ada dua belas. 1. Jual beli memenuhi rukun akad. 2. Barang yang dijual belikan diketahui, untuk menghindari ketidak jelasan (jahalah), karena bisa menimbulkan perselisihan. 3. Harganya diketahui sebagaimana barang yang dijual belikan. 4. Berlaku untuk selamanya. Jual beli yang dibatasi waktu tidak diperkenankan syara', karena jual beli menghendaki perpindahan kepemilikan sempurna. 5. Waktu pembayarannya diketahui. Syarat ini untuk jual beli yang pembayarannya ditangguhkan. 6. Barang yang dijual belikan bisa diserah terimakan tanpa menimbulkan bahaya. 7 . Terjaminnya kerelaan kedua belah pihak. 8. Harganya (pertukarannya) adalah sesuatu yang berharga. 9. Tidak ada gharar (sesuatu yang tidak jelas; barangnya atau akibatnya). 10. Tidak adanya sesuatu yang menyebabkan akad menjadi fasad. 11. Tidak ditemukan syarat yang rusak. 12. Tidak mengandung riba ${ }^{26}$. Definisi riba menurut madzhab Hanafi adalah tambahan tanpa iwadh dalam pertukaran harta dengan harta. Menurut pendapat madzhab Syafi'i adalah akad iwadh khusus yang tidak diketahui kesepadanannya dalam standart syari'ah pada saat akad, atau disertai pengunduran waktu pertukaran keduanya atau salah satunya ${ }^{27}$. Kedua definisi tersebut berpijak pada dasar adanya tambahan dan atau pengunduran waktu pertukaran sebagai penentu ada atau tidaknya riba. Definisi ulama' klasik di atas berbeda dengan pandangan kaum modernis yang melihat keharaman riba ada pada kedhalimannya, bukan semata-mata tambahannya. Mereka diantaranya adalah Fazlurrahman, Muhammad Asad, Sa'id al-Najjar, dan Abdul Mun'im al-Namr. Rasyid Rihho dan gurunya Muhammad Abduh berpendapat bahwa penambahan yang pertama dalam suatu utang tertentu adalah halal tetapi jika pada saat jatuh tempo, ditetapkan untuk menunda jatuh tempo dengan imbalan tambahan lagi, maka tambahan yang kedua adalah haram ${ }^{28}$.

${ }^{26}$ Ibid, Musa, h.241-244

${ }^{27}$ Ibid, Musa, h.253

${ }^{28}$ Saeed, Loc Cit, h.62-64 


\section{Jenis-jenis jual beli}

Jenis-jenis jual beli dikategorikan sesuai dengan kebutuhan penjelasan masing-masing fuqaba', disamping ada logika yang melatar belakanginya. Kategorisasi pada kitab tertentu belum tentu sama dengan kitab lainnya. Kitab-kitab fiqh Syafi'iyah yang sederhana pembahasannya membagi jual beli menjadi tiga, seperti yang dilakukan Taqiyuddin dalam kitab Kifayatul Akbyar. 1. Jual beli barang yang dapat disaksikan (wujud). Jual beli barang tersebut hukumnya boleh. 2. Jual beli barang yang disebut sifatnya saja dan belum wujud. Jual beli barang tersebut hukumnya boleh. 3. Jual beli barang yang tidak ada dan tidak dapat disaksikan. Jual beli tersebut hukumnya tidak boleh ${ }^{29}$.

Kamil Musa membagi menjadi empat. 1. Jual beli muqayadhah yaitu jual beli barang dengan barang. Ia biasa dikenal dengan barter. 2. Sarf yaitu jual beli harga (mata uang) dengan harga (mata uang). Artinya pertukaran mata uang sejenis maupun jenis mata uang lainnya. 3. Salam. Jual beli barang yang belum ada pada saat akad, harganya dibayar pada saat akad. 4. Jual beli mutlak yaitu jual beli barang dengan harga (mata uang) ${ }^{30}$.

Menurut Ibnu Rusyd, setiap kegiatan mu'amalah yang melibatkan dua belah pihak, memiliki tiga kemungkinan. 1. Pertukaran barang dengan barang. 2. Pertukaran barang dengan sesuatu dalam tanggungan. 3. Sesuatu dalam tanggungan dengan sesuatu dalam tanggungan. Ketiga kemungkinan tersebut adakalanya dilakukan secara kontan adakalanya dilakukan secara tangguh. Adakalanya kontan oleh kedua belah pihak, adakalanya tangguh oleh kedua belah pihak, adakalanya kontan oleh satu pihak sedangkan pihak yang lain tangguh. Jual beli barang atau tanggungan yang dilakukan secara tangguh oleh kedua belah pihak tidak diperkenankan oleh ijma' ulama', karena termasuk jual beli yang dilarang, yaitu utang ditukar utang. Ada beberapa nama jual beli menurut sifat dan keadaan akad. 1. Jual beli harga/uang dengan harga/uang disebut sarf. 2. Jual beli barang dengan uang/harga disebut jual beli mutlak, termasuk di dalamnya jual beli harga dengan barang yang menggunakan syarat.

29 Al-Dimasyqi, Loc Cit, h. 239-240

${ }^{30}$ Musa, Loc Cit, h. 216-233

Volume IV/Edisi 1/Mei 2013 
Konsep Jual Beli dalam Fatwa DSN-MUI

3. Uang dengan barang yang dalam tanggungan disebut salam. 4. Jual beli khiyar (jual beli dalam perjanjian ). 5. Jual beli murababah. 6. Jual beli muzayadah31.

Kamil Musa lebih lanjut membagi jenis jual beli mutlak berdasarkan beberapa dasar pemikiran. Pertama, dilihat dari keabsahan akad, ada tiga. 1 . Jual beli shabih yaitujual beli yang memenuhi syarat-syarat akad dan syarat syahnya akad. 2. Jual beli fasid yaitu jual beli yang memenuhi syarat akad tetapi tidak memenuhi syarat syahnya akad. 3. Jual beli bathil yaitu jual beli yang tidak memenuhi syarat akad, baik memenuhi syarat syah atau tidak memenuhi syarat syah. Contohnya menjual atau membeli barang haram seperti babi dan bangkai. Pembagian Kedua didasarkan pada lanjut dan tidaknya jual beli, ada dua. 1. Jual beli yang berlanjut yaitu jual beli shabib yang dilakukan orang yang memiliki kewenangan menjual beli. 2. Jual beli manquf yaitu jual beli shahib yang dilakukan orang yang tidak memiliki kewenangan seperti anak kecil. Jual belinya tidak bisa lanjut kecuali atas persetujuan wali atau orang tuanya. Pembagian ketiga berdasarkan kepastian jual beli.1. Jual beli pasti yaitu jual beli shabih dan tidak ada khiyar lagi. 2. Jual beli belum pasti yaitu jual beli shabih yang masih dalam khiyar. Pembagian keempat berdasarkan penyebutan ganti. 1. Jual beli musawiyah yaitu jual beli dimana penjual dan pembeli telah sepakat harga dan penjual tidak menyebut harga belinya (Jawa: kulakan). 2. Jual beli murabahah yaitu jual beli dengan member kelebihan/keuntungan. 3. Jual beli tauliyah yaitu jual beli dengan sesuatu yang ada padanya seperti dibayar pakai upah $^{32}$.

\section{Jual Beli Yang Dilarang}

Dalam pandangan hukum Islam ada larangan dalam melakukan jual beli. Ada empat sebab-sebab fasid (rusaknya jual beli), yaitu: 1. Barang yang dijual adalah haram. 2. Riba. 3.Gharar. 4. Syarat-syarat yang mengarah kepada riba dan gharar. Larangan tersebut bergantung pada internal akad. Ada lagi faktor eksternal akad yang menyebabkan jual beli dilarang, yaitu ghasy (pemalsuan), dharar (bahaya), waktu yang tidak tepat dan jual beli yang diharamkan. Menjual barang yang dilarang ada dua kategori, yaitu barang najis

${ }^{31}$ Rusyd, Ibnu, t.th., Bidayah al-Mujtabid, Juz.3, Beirut, Dar al-Fikr. H.93

32 Musa, Loc Cit, h.245-249 
dan barang tidak najis. Para ulama' sepakat melarang barang najis yang menimbulkan bahaya diperjual belikan seperti khamr (Jawa: arak), bangkai dan babi. Para ulama' berbeda pendapat tentang jual beli barang najis yang menimbulkan manfaat seperti pupuk ${ }^{33}$. Madzhab Syafi'i dan sebagian Maliki melarang jual beli barang najis menskipun bermanfaat, sedangkan sebagian madzhab Maliki, madzhab Hanbali dan Hanafi membolehkannya ${ }^{34}$. Para ulama' tidak sepakat melarang menjual barang yang tidak najis seperti anjing dan kucing 35 .

Para ulama' sepakat keharaman riba yang terjadi pada dua hal; jual beli dan sesuatu yang ada pada tanggungan, baik berupa jual beli, pesanan atau yang lain. Riba pada tanggungan ada dua jenis. 1. Riba jabiliyah yaitu kedua belah pihak sepakat menunda pembayaran utang dengan memberi tambahan. 2. Menunda. Riba pada jual beli terjadi pada dua hal yaitu; tambahan dan penundaan ${ }^{36}$.

Gharar terjadi pada beberapa kasus. 1. Barang yang dijual tidak jelas. Dalam kasus tersebut adakalanya barang yang dijual tidak jelas batasannya atau batasan akadnya tidak jelas. 2. Terjadi pada kasus harga dan barang yang dihargai tidak jelas atau ukurannya tidak jelas, tenggang waktu pembayarannya tidak jelas untuk jual beli yang pembayarannya tunda. 3. Tidak diketahui wujudnya atau diragukan kemampuannya, artinya kemampuan untuk serah terima barang. 4. Pada kasus tidak diketahui keselamatan kekekalan barangnya. Diantara jual beli yang mengandung ciri-ciri dharar di atas ada yang disebut namanya dalam nash (Hadits) dan jual beli yang tidak disebut namanya oleh nash. Jual beli yang disebut namanya oleh nash adalah tradisi jabiliyah yang dilarang Nabi, para ulama' sepakat terhadap larangannya, seperti 1 . Jual beli hewan dalam kandungan dengan sebutan bai' al-habl al-bablah, baik bayi hewan dalam kandungan yang disebut madhamin maupun hasil peranakan pejantan yang disebut mulaqih. 2. Jual beli mulamasah, yaitu jual beli barang dengan cara disentuh pada malam hari yang gelap hingga tidak diketahui sejatinya barang

\footnotetext{
${ }^{33}$ Rusyd, Op Cit, h.94

34 al-Jaziri, Abdurrabman, 2003, al-Fiqh 'Ala al-Madzabibal-Arba'ah, Juz: 2, Dar al-Taqwa Li alThab'I Wa al-Nasyar Wa al-Tauzi'.176-177

${ }^{35}$ Rusyd, Op Cit, h.94

${ }^{36}$ Ibid, Rusyd, h.96
} 
Konsep Jual Beli dalam Fatwa DSN-MUI

tersebut. 3. Jual beli munabadhah yaitu penjual dan pembeli saling melempar barang hingga tidak jelas barang yang mana yang dipertukarkan. 4. Jual beli Khashat yaitu jual beli dengan cara melempar batu pada dagangan dan yang kena berarti yang dibeli dan wajib dibeli. 5. Jual beli menggunakan dua akad yang diberi sebutan bai'ataini fi ba'iatin. 6. Jual beli buah-buahan sebelum jelas baiknya. Jual beli yang tidak disebut namanya oleh nash ulama' berbeda pendapat ${ }^{37}$.

\section{Jual Beli Dalam Fatwa DSN-MUI}

\section{Mekanisme penetapan Fatwa DSN-MUI}

Kehadiran fatwa DSN-MUI adalah kebutuhan para praktisi ekonomi syari'ah dalam melakukan kegiatan transaksi, khususnya di lembaga keuangan syari'ah (LKS). Kehadiran fatwa DSN-MUI didahului oleh kegiatan lembaga keuangan syari'ah. Bank syari'ah telah beroperasi mulai tahun 1992, perusahaan asuransi syariah mulai beroperasi tahun 1994 dan pasar modal syari'ah mulai beroperasi tahun 1997 (Barlinti, 2010: 143)38. LKS tersebut semuanya memiliki Dewan Pengawas Syari'ah (DPS) sebagai kelengkapan kelembagaan, yang berfungsi mengawasi dan member fatwa tentang persoalan kesyariahan produk LKS. Fatwa yang dikeluarkan masing-masing DPS bersifat mengikat terbatas. Keterbatasan fatwa DPS tersebut melahirkan kebutuhan adanya lembaga fatwa yang menjadi acuan kegiatan LKS secara nasional ${ }^{39}$.

Keinginan membuat lembaga fatwa berskala nasional diwujudkan pada tahun 1999 M. Dalam lokakarya ulama' tentang reksadana syari'ah pada tanggal 29-30 Juli 1997, merekomendasikan untuk membuat suatu lembaga sebagai wadah atas kebutuhan para praktisi ekonomi. Atas dasar rekomendasi tersebut, MUI membentuk Dewan Syari'ah Nasional (DSN) pada tanggal 10 Februari 1999 melalui SK MUI no.Kep-754/MUI/II/1999 tentang pembentukan Dewan Syari'ah Nasional (DSN). Anggota DSN terdiri dari para

${ }^{37}$ Ibid, Rusyd, h.111

38 Barlinti, Yeni Salma, 2010, Kedudukan Fatwa Dewan Syariah Nasional Dalam Sistem Hukum Nasional, Jakarta, Balitbang dan Diklat Kemenag RI. H.143

${ }^{39}$ Ibid, Barlinti, h.144 
ulama', praktisi dan pakar yang terkait dengan muamalah syariah. Mereka ditunjuk dan diangkat oleh MUI untuk empat tahun ${ }^{40}$.

Tugas DSN-MUI adalah mengeluarkan fatwa dan mengawasi penerapan fatwa. Secara rinci ada 3 tugas DSN-MUI. 1. Menumbuh kembangkan nilai syari'ah pada lembaga keuangan syari'ah dan lembaga perekonomian non keuangan. 2. Mengeluarkan fatwa atas jenis-jenis kegiatan keuangan dan fatwa atas produk dan jasa keuangan syari'ah. 3. Mengawasi penerapan fatwa yang telah dikeluarkan ${ }^{41}$. Dalam mekanisme kegiatan tugas DSN-MUI, keberadaan DPS di setiap LKS, ditempatkan pada salah satu pelaksana tugas DSN-MUI yaitu sebagai pengawas pelaksanaan fatwa DSNMUI $^{42}$.

Kewenangan DSN-MUI sangat kuat dalam menata pelaksanaan nilainilai syari'ah pada LKS. Menurut keputusan DSN-MUI no.1 tahun 2000, ia memiliki enam kewenangan. 1. Mengeluarkan fatwa yang mengikat DPS di masing-masing LKS dan menjadi dasar tindakan hukum pihak terkait. 2 . Mengeluarkan fatwa yang menjadi landasan bagi ketentuan yang dikeluarkan oleh instansi yang berwenang, seperti Departemen Keuangan dan BI (Bank Indonesia). 3. Memberi rekomendasi dan atau mencabut rekomendasi namanama yang duduk sebagai DPS pada suatu LKS. 5. Mengundang para ahli untuk menjelaskan suatu masalah yang diperlukan, dalam pembahasan ekonomi syari'ah, termasuk otoritas moneter/lembaga keuangan dalam dan luar negeri. 5. Memberikan peringatan kepada LKS untuk menghentikan penyimpangan dari fatwa yang telah dikeluarkan oleh DSN-MUI. 6. Mengusulkan kepada instansi yang berwenang untuk mengambil tindakan apabila peringatan tidak diindahkan ${ }^{43}$.

Tugas mengeluarkan fatwa atas jenis kegiatan keuangan syari'ah serta produk dan jasa keuangan syari'ah memerlukan serangkaian proses. Ia dilakukan melalui rapat pleno yang dihadiri semua anggota DSN-MUI, Bank Indonesia (BI) atau lembaga keuangan lainnya dan pelaku bisnis syari’ah.

40 Ibid, Barlinti, h.145-146

${ }^{41}$ Keputusan Dewan Syari'ah Nasional Majelis Ulama' Indonesia Nomor 1 Tahun 2001. H.2

42 Barlinti, Op cit, h. 146

${ }^{43}$ Keputusan Dewan Syari'ah Nasional Majelis Ulama' Indonesia Nomor 1 Tahun 2001. H.3 
Konsep Jual Beli dalam Fatwa DSN-MUI

Alur penetapan fatwa DSN-MUI secara urut sebagai berikut. Pertama, badan pelaksana harian DSN-MUI menerima usulan atau pertanyaan hukum mengenai suatu produk LKS. Usulan bisa disampaikan melalui DPS yang ada pada setiap LKS atau bisa disampaikan secara langsung kepada sekretariat badan pelaksana harian (BPH) DSN-MUI. Kedua, sekretariat yang dilaksanakan oleh sekretaris paling lambat satu hari kerja setelah menerima usulan wajib menyampaikan permasalahan kepada ketua. Ketiga, BPH DSNMUI bersama anggota dan staf ahli selambat-lambatnya 20 hari kerja wajib membuat memorandum khusus yang berisi telaah dan pembahasan terhadap suatu pertanyaan atau usulan hukum tersebut. Keempat, ketua BPH DSNMUI selanjutnya membawa hasil pembahasan ke rapat pleno DSN-MUI untuk mendapat pengesahan. Kelima, memorandum yang telah mendapat pengesahan rapat pleno DSN-MUI ditetapkan menjadi fatwa DSN - MUI dengan ditandatangani oleh ketua DSN-MUI (ex officio ketua umum MUI) dan sekretaris DSN-MUI (ex officio sekretaris umum MUI) ${ }^{44}$.

Fatwa DSN-MUI yang telah ada, keberlakuannya ada yang terbatas pada bidang usaha tertentu ada juga yang bersifat umum. Pada kurun waktu 2000 sampai dengan 2008 telah ada 75 fatwa. 24 fatwa berlaku khusus untuk bidang usaha perbankan syari'ah. Fatwa-fatwa tersebut dalam pertimbangan dan keputusannya menunjukkan dengan jelas peruntukannya untuk kegiatan perbankan syari'ah seperti produk funding (pendanaan), produk lending (murabahah), produk jasa dan sertifikat Bank Indonesia maupun transaksi antar bank syari'ah. 5 fatwa berlaku untuk bidang asuransi syari'ah dan reasuransi syari'ah. Fatwa-fatwa tersebut dalam pertimbangan dan keputusannya menunjukkan peruntukan hanya untuk asuransi dan reasuransi, seperti pedoman pelaksanaan asuransi, produk asuransi dan penggunaan beberapa akad pada produk asuransi. 11 fatwa untuk bidang usaha pasar modal. Fatwafatwa tersebut berkaitan dengan kegiatan operasional pasar modal seperti pedoman tentang obligasi, reksadana, SBSN dan penggunaan akad dalam kegiatan pasar modal. 35 fatwa untuk bidang umum. Fatwa-fatwa tersebut tidak dikhususkan untuk lembaga keuangan tertentu seperti perbankan syari'ah maupun pegadaian syari'ah atau lainnya. Fatwa-fatwa tersebut bisa dipergunakan pada kegiatan transaksi yang ada di lembaga keuangan syari'ah

${ }^{44}$ Barlinti, Loc Cit, h.158-159 
bank maupun non bank. Fatwa- fatwa tersebut berkaitan dengan akad-akad syari'ah seperti jual beli (selain murabahab), kerjasama dan jasa, pedoman transaksi yang bersifat umum seperti sistem dan prinsip distribusi hasil usaha pada $\mathrm{LKS}^{45}$.

DSN-MUI menggunakan 3 pendekatan dalam memutuskan fatwa. Pertama, pendekatan nash qath'i, pendekatan qauli dan pendekatan manhaji. Pendekatan pertama, dilakukan dengan berpegang kepada nash al-Qur'an atau Hadits untuk suatu masalah yang terdapat dalam al-Qur'an atau Hadits secara jelas. Dalam hal permasalahan yang dikaji tidak terdapat secara jelas ketentuannya dalam al-Qur'an atau Hadits, maka dilakukan dengan pendekatan qauli dan manhaji. Pendekatan qauli artinya pendekatan dalam proses penetapan fatwa dengan mendasarkannya pada pendapat para imam madz̧hab dalam kitab fiqh mu'tabarah. Ia dilakukan dalam hal masalah yang dikaji dibahas di kitab-kitab mu'tabarah, hanya ada satu pendapat dan kajian di dalamnya masih relevan. Dalam hal kajian dalam kitab tersebut tidak relevan lagi karena beberapa hal, maka dilakukan kajian ulang. Artinya teks-teks pendapat hukum dalam kitab mu'tabarah tidak mencukupi maka fatwa diputuskan dengan pendekatan lainnya, yaitu manhaji. ketiga, yaitu manhaji. Ia adalah pendekatan yang menggunakan kaidah ushuliyah dan kaidah fiqbiyah, dan kaidah-kaidah yang biasa dipakai para ulama' terdahulu. Pendekatan manhaji dilakukan secara kolektif (ijtihad jama'i), dengan menggunakan cara tarjih (memilih pendapat yang paling kuat, diantara beberapa pendapat ulama'), ilhaq (mempertemukan berbagai pendapat ulama') dan istinbath (menggali hukum) ${ }^{46}$. Penulis belum menemukan contoh aplikasi tiga pendekatan secara tegas dalam konsideran fatwa-fatwa DSN-MUI tentang jual beli. Dalam konsideran selalu ada nash dan kaidah fiqhiyyah. Apakah ia masuk qath'i atau manhaji.

\section{Fatwa DSN-MUI Tentang Jual Beli}

1. Fatwa tentang tata cara jual beli ada pada fatwa nomor: 04/DSNMUI/IV/2000 tentang jual beli murabahah. Ia berisi enam bagian.

Pertama, ketentuan umum murabahah dalam bank syari'ah, yaitu:

${ }^{45}$ Ibid, Barlinti, h.167-171

${ }^{46}$ Ibid, Barlinti, h.142-143 
Konsep Jual Beli dalam Fatwa DSN-MUI

a. Bank dan nasabah harus melakukan akad murabahah yang bebas riba.

b. Barang yang diperjual belikan tidak diharamkan oleh syari'at Islam.

c. Bank membiayai sebagian atau seluruh harga pembelian barang yang telah disepakati kualifikasinya.

d. Bank membeli barang yang diperlukan nasabah atas nama bank sendiri, dan pembelian ini harus sah dan bebas riba.

e. Bank harus menyampaikan semua hal yang berkaitan dengan pembelian, misalnya jika pembelian dilakukan secara utang.

f. Bank kemudian menjual barang tersebut kepada nasabah (pemesan) dengan harga jual senilai harga plus keuntungannya. Dalam kaitan ini bank harus memberitahu secara jujur harga pokok barang kepada nasabah berikut biaya yang diperlukan.

g. Nasabah membayar harga barang yang telah disepakati tersebut pada jangka waktu tertentu yang telah disepakati.

h. Untuk mencegah terjadinya penyalahgunaan atau kerusakan akad tersebut, pihak bank dapat mengadakan perjanjian khusus dengan nasabah.

i. Jika bank hendak mewakilkan kepada nasabah untuk membeli barang dari pihak ketiga, akad jual beli murabahab harus dilakukan setelah barang, secara prinsip menjadi milik bank.

Kedua, Ketentuan murabahab kepada nasabah

a. Nasabah mengajukan permohonan dan janji pembelian suatu barang atau asset kepada bank.

b. Jika bank menerima permohonan tersebut, ia harus membeli terlebih dahulu asset yang dipesannya secara sah dengan pedagang.

c. Bank kemudian menawarkan asset tersebut kepada nasabah dan nasabah harus menerimanya (membeli) sesuai dengan janji yang telah disepkatinya, karena secara hukum janji tersebut mengikat, kemudian kedua belah pihak membuat kontrak jual beli.

d. Dalam jual beli ini bank dibolehkan meminta nasabah untuk membayar uang muka saat menandatangani kesepakatan awal pemesanan.

e. Jika nasabah kemudian menolak membeli barang tersebut, biaya riil bank harus dibayar dari uang muka tersebut. 
f. Jika nilai uang muka kurang dari kerugian yang harus ditanggung oleh bank, bank dapat meminta kembali sisa kerugiannya kepada nasabah.

g. Jika uang muka memakai kontrak 'urbun sebagai alternatif dari uang muka, maka: pertama, jika nasabah memutuskan untuk membeli barang tersebut, ia tinggal membayar sisa harga. Kedua, jika nasabah batal membeli, uang muka menjadi milik bank maksimal sebesar kerugian yang ditanggung oleh bank akibat pembatalan tersebut dan jika uang muka tidak mencukupi, nasabah wajib melunasi kekurangannya.

Ketiga: jaminan dalam murabahah

a. Jaminan murabahah dibolehkan, agar nasabah serius dengan pesanannya.

b. Bank dapat meminta nasabah untuk menyediakan jaminan yang dapat dipegang.

Keempat : utang dalam murabahah

a. Secara prinsip, penyelesaian utang nasabah dalam transaksi murabahah tidak ada kaitannya dengan transaksi lain yang dilakukan nasabah dengan pihak ketiga atas barang tersebut. Jika nasabah menjual kembali barang tersebut dengan keuntungan atau kerugian, ia tetap berkewajiban untuk menyelesaikan utangnya kepada bank.

b. Jika nasabah menjual barang tersebut sebelum masa angsuran berakhir, ia tidak wajib segera melunasi seluruh angsurannya.

c. Jika penjualan barang tersebut menyebabkan kerugian, nasabah harus tetap menyelesaikan utangnya sesuai kesepakatan awal. Ia tidak boleh memperlambat pembayaran angsuran atau meminta kerugian itu diperhitungkan.

Kelima : penundaan pembayaran dalam murababah

a. Nasabah yang memiliki kemampuan tidak dibenarkan menunda penyelesaian utangnya.

b. Jika nasabah menunda - nunda pembayaran dengan sengaja, atau jika salah satu pihak tidak menunaikan kewajibannya, maka penyelesaiannya dilakukan melalui Badan Arbitrase Syari'ah setelah tidak tercapai kesepakatan melalui musyawarah. 
Konsep Jual Beli dalam Fatwa DSN-MUI

Keenam : Bangkrut dalam murabahah.

Jika nasabah telah dinyatakan pailit dan gagal menyelesaikan utangnya, bank harus menunda tagihan utang sampai ia menjadi sanggup kembali atau berdasarkan kesepakatan ${ }^{47}$.

\section{Jual beli salam}

Fatwa tentang jual beli salam dicantumkan pada fatwa nomor: 05/DSN-MUI/IV/2000. Ia memuat enam ketentuan.

Pertama, ketentuan tentang pembayaran

a. Alat bayar harus diketahui jumlah dan bentuknya, baik berupa uang, barang atau manfaat.

b. Pembayaran harus dilakukan pada saat kontrak disepakati

c. Pembayaran tidak boleh dalam bentuk pembebasan utang.

Kedua, ketentuan tentang barang

a. Harus jelas ciri-cirinya dan dapat diakui sebagai utang.

b. Harus dapat dijelaskan spesifikasinya.

c. Penyerahannya dilakukan kemudian

d. Waktu dan tempat penyerahan barang harus ditetapkan berdasarkan kesepakatan.

e. Pembeli tidak boleh menjual barang sebelum menerimanya.

f. Tidak boleh menukar barang, kecuali dengan barang sejenis sesuai kesepakatan.

Ketiga, Ketentuan tentang salam paralel. Dibolehkan melakukan salam paralel dengan syarat, akad kedua terpisah dari, dan tidak berkaitan dengan akad pertama.

Keempat, penyerahan barang sebelum atau pada waktunya:

a. Penjual harus menyerahkan barang tepat pada waktunya dengan kualitas dan jumlah yang telah disepakati.

47 Himpunan Fatwa Dewan Syari'ah Nasional, 2006, Jakarta, Dewan Syari'ah NasionalMajelis Ulama' Indonesia dan Bank Indonesia. H.24-27 
b. Jika penjual menyerahkan barang dengan kualitas yang lebih tinggi, penjual tidak boleh meminta tambahan harga.

c. Jika penjual menyerahkan barang dengan kualitas yang lebih rendah, dan pembeli rela menerimanya, maka ia tidak boleh menuntut pengurangan harga (diskon).

d. Penjual dapat menyerahkan barang lebih cepat dari waktu yang disepakati dengan syarat kualitas dan jumlah barang, sesuai dengan kesepakatan, ia tidak boleh menuntut tambahan harga.

e. Jika semua atau sebagian barang tidak tersedia pada waktu penyerahan, atau kualitasnya lebih rendah dan pembeli tidak rela menerimanya, maka ia memiliki dua pilihan. Pertama, membatalkan kontrak dan meminta kembali uang. Kedua, menunggu sampai barang tersedia.

Kelima, pembatalan kontrak. Pada dasarnya pembatalan salam boleh dilakukan selama tidak merugikan kedua belah pihak.

Keenam, perselisihan. Jika terjadi perselisihan diantara kedua belah pihak, maka persoalannya diselesaikan melalui badan arbitrase syari'ah setelah tidak tercapai kesepakatan ${ }^{48}$.

\section{Jual beli istishna'.}

Ada tiga ketentuan tentang jual beli istishna'.

Pertama, ketentuan tentang pembayaran:

a. Alat bayar harus diketahui jumlah dan bentuknya, baik berupa uang, barang atau manfaat.

b. Pembayaran dilakukan sesuai dengan kesepakatan.

c. Pembayaran tidak boleh dalam bentuk pembebasan utang.

Kedua, ketentuan tentang barang

a. Harus jelas cirri - cirinya dan dapat diakui sebagai utang.

b. Harus dapat dijelaskan spesifikasinya.

c. Penyerahannya dilakukan kemudian.

d. Waktu dan tempat penyerahan barang harus ditetapkan berdasarkan kesepakatan.

${ }^{48}$ Ibid, Himpunan, h.29-34

Volume IV/Edisi 1/Mei 2013 
Konsep Jual Beli dalam Fatwa DSN-MUI

e. Pembeli (mustashni) tidak boleh menjual barang sebelum menerimanya.

f. Tidak boleh menukar barang, kecuali dengan barang sejenis sesuai kesepakatan.

g. Dalam hal terdapat cacat atau barang tidak sesuai dengan kesepakatan, pemesan memiliki hak khiyar (hak memilih) untuk melanjutkan atau membatalkan akad.

Ketiga, ketentuan lain.

a. Dalam hal pesanan sudah dikerjakan sesuai dengan kesepakatan, hukumnya mengikat.

b. Semua ketentuan dalam jual beli salam yang tidak disebutkan di atas berlaku pula pada jual beli istishna'.

c. Jika salah satu pihak tidak menunaikan kewajibannya atau jika terjadi perselisihan antara kedua belah pihak, maka penyelesainnya dilakukan melalui badan arbitrase syari'ah setelah tidak tercapai kesepakatan melalui musyawarah (Himpunan, 2006: 37-38) ${ }^{49}$.

\section{Uang Muka Dalam Murabahah.}

Ketentuan pokok tentang uang muka dalam murabahah. Sebagai berikut:

a. Dalam akad pembiayaan murabahah, lembaga keuangan syari'ah dibolehkan untuk meminta uang muka apabila kedua belah pihak bersepakat.

b. Besar jumlah uang muka ditentukan berdasarkan kesepakatan.

c. Jika nasabah membatalkan akad murabahah, nasabah harus memberikan ganti rugi kepada LKS dari uang muka tersebut.

d. Jika jumlah uang muka lebih kecil dari kerugian, LKS dapat meminta tambahan kepada nasabah.

e. Jika jumlah uang muka lebih besar dari kerugian, LKS harus mengembalikan kelebihannya kepada nasabah ${ }^{50}$.

${ }^{49}$ Ibid, Himpunan, h.37-38

${ }^{50}$ Ibid, Himpunan, h.81-82 


\section{Diskon Dalam Murabahah.}

Ketentuan pokok tentang diskon dalam murabahah sebagai berikut:

a. Harga (tsaman) dalam jual beli adalah suatu jumlah yang disepakati oleh kedua belah pihak, baik sama dengan nilai (qimab) benda yang menjadi obyek jual beli, lebih tinggi maupun lebih rendah.

b. Harga dalam jual beli murabahah adalah harga beli dan biaya yang diperlukan ditambah keuntungan sesuai dengan kesepakatan.

c. Jika dalam jual beli murabahah LKS mendapat diskon dari supplier, harga sebenarnya adalah harga setelah diskon, karena itu diskon adalah hak nasabah.

d. Jika pemberian diskon terjadi setelah akad, pembagian diskon tersebut dilakukan berdasarkan perjanjian (persetujuan) yang dimuat dalam akad.

e. Dalam akad, pembagian diskon setelah akad hendaklah diperjanjikan dan ditanda tangani ${ }^{51}$.

\section{Sanksi Atas Nasabah Mampu Yang Menunda-Nunda Pembayaran.}

Ketentuan umum tentang fatwa tersebut sebagai berikut:

a. Sanksi yang disebut dalam fatwa ini adalah sanksi yang dikenakan LKS kepada nasabah yang mampu membayar, tetapi menunda-nunda pembayaran dengan sengaja.

b. Nasabah yang tidak / belum mampu membayar disebabkan force majeur tidak boleh dikenakan sanksi.

c. Nasabah mampu yang menunda-nunda pembayaran dan/atau tidak mempunyai kemauan dan itikad baik untuk membayar utangnya boleh dikenakan sanksi.

d. Sanksi didasarkan pada prinsip ta'zir, yaitu bertujuan agar nasabah lebih disiplin dalam melaksanakan kewajibannya.

e. Sanksi dapat berupa denda sejumlah uang yang besarnya ditentukan atas dasar kesepakatan dan dibuat saat akad ditanda tangani.

f. Dana yang berasal dari denda diperuntukkan sebagai dana social ${ }^{52}$.

${ }^{51}$ Ibid, Himpunan, h.94-95

52 Ibid, Himpunan, h.110-111

Volume IV/Edisi 1/Mei 2013 
Konsep Jual Beli dalam Fatwa DSN-MUI

\section{Fatwa Tentang Jual Beli Istishna' Parallel.}

Ketentuan umum tentang fatwa tersebut adalah sebagai berikut:

a. Jika LKS melakukan transaksi istishna' untuk memenuhi kewajibannya kepada nasabah ia dapat melakukan istishna' lagi dengan pihak lain pada objek yang sama, dengan syarat istishna' pertama tidak bergantung (mu'allaq) pada istishna' kedua.

b. LKS selaku mustashni' tidak diperkenankan untuk memungut MDC (margin during construction) dari nasabah (shani) karena hal ini tidak sesuai dengan prinsip syari'ah.

c. Semua rukun dan syarat yang berlaku dalam akad istishna' (fatwa no.6) berlaku pula dalam istishna' paralel ${ }^{53}$.

\section{Fatwa Tentang Potongan Pelunasan Dalam Murabahah}

Ketentuan umum tentang fatwa ini adalah sebagai berikut:

a. Jika nasabah dalam transaksi murabahah melakukan pelunasan pembayaran tepat waktu atau lebih cepat dari waktu yang telah disepakati, LKS boleh memberikan potongan dari kewajiban pembayaran tersebut, dengan syarat tidakdi perjanjikan.

b. Besar potongan sebagaimana dimaksud di atas diserahkan pada kebijakan dan pertimbangan LKS ${ }^{54}$.

\section{Fatwa ljarah Muntahiyyah Bi al-Tamlik}

Ada dua ketentuan pokok dalam fatwa tersebut.

Pertama, ketentuan umum. Akad ijarah muntahiyyah bi al-tamlik boleh dilakukan dengan ketentuan sebagai berikut:

a. Semua rukun dan syarat yang berlaku dalam akad ijarah (fatwa no.09) berlaku pula dalam akad al-ijarah al-muntabiyyah bi al-tamlik.

b. Perjanjian untuk melakukan akad jjarah al-muntahiyyah bi al-tamlik harus disepakati ketika akad jjarah ditanda tangani.

c. Hak dan kewajiban setiap pihak harus dijelaskan dalam akad.

Kedua, ketentuan tentang al-ijarah al-muntabiyyah bi al-tamlik.

${ }^{53}$ Ibid, Himpunan, h.138-139

${ }^{54}$ Ibid, Himpunan, h.144 
a. Pihak yang melakukan al-ijarah al-muntahiyyah bi al-tamlik harus melaksanakan akad jjarah terlebih dahulu. Akad pemindahan kepemilikan, baik dengan jual beli atau pemberian, hanya dapat dilakukan setelah masa ijarah selesai.

b. Janji pemindahan kepemilikan yang disepakati di awal akad ijarah adalah wa'd, yang hukumnya tidak mengikat. Apabila janji itu ingin dilaksanakan, maka harus ada akad pemindahan kepemilikan yang dilakukan setelah masa ijarah selesai ${ }^{55}$.

\section{Jual Beli Mata Uang (al-sarf)}

Ada dua ketentuan pokok dalam keputusan fatwa tersebut.

Pertama, ketentuan umum. Transaksi jual beli mata uang pada prinsipnya boleh dengan ketentuan sebagai berikut:

a. Tidak untuk spekulasi (untung-untungan).

b. Ada kebutuhan transaksi atau untuk berjaga-jaga (simpanan).

c. Apabila transaksi dilakukan terhadap mata uang sejenis maka nilainya harus sama dan secara tunai.

d. Apabila berlainan jenis maka harus dilakukan dengan nilai tukar (kurs) yang berlaku pada saat transaksi dilakukan dan secara tunai.

Kedua, jenis - jenis transaksi valuta asing.

a. Transaksi Spot, yaitu transaksi pembelian dan penjualan valuta asing (valas) untuk penyerahan pada saat itu (over the counter) atau penyelesaiannya paling lambat dalam jangka waktu dua hari. Hukumnya adalah boleh, karena dianggap tunai, sedangkan waktu dua hari dianggap sebagai proses penyelesaian yang bisa dihindari dan merupakan transaksi internasional.

b. Transaksi forward, yaitu transaksi pembelian dan penjualan valas yang nilainya ditetapkan pada saat sekarang dan diberlakukan untuk waktu yang akan datang, antara 2x24 jam sampai dengan satu tahun. Hukumnya adalah haram, karena harga yang digunakan adalah harga yang diperjanjikan (muwa'adah) dan penyerahannya dilakukan di kemudian hari, padahal harga pada waktu penyerahan tersebut belum

${ }^{55}$ Ibid, himpunan, h.161-162 
Konsep Jual Beli dalam Fatwa DSN-MUI

tentu sama dengan nilai yang disepakati, kecuali dilakukan dalam bentuk forward agreement untuk kebutuhan yang tidak dapat dihindari (lil hajah).

c. Transaksi swap, yaitu suatu kontrak pembelian atau penjualan valas dengan harga spot yang dikombinasikan dengan pembelian antara penjualan valas yang sama dengan harga forward. Hukumnya haram, karena mengandung unsur maisir (spekulasi).

d. Transaksi option, yaitu kontrak untuk memperoleh hak dalam rangka membeli atau hak untuk menjual yang tidak harus dilakukan atas sejumlah unit valuta asing pada harga dan jangka waktu atau tanggal akhir tertentu. Hukumnya haram, karena mengandung unsur maisir (spekulasi) ${ }^{56}$.

\section{Potongan Tagihan Murabahah.}

Ketentuan pokok dalam fatwa tersebut.

Pertama, ketentuan pemberian potongan

a. LKS boleh memberikan potongan dari total kewajiban pembayaran kepada nasabah dalam transaksi (akad) murabahah yang telah melakukan kewajiban pembayaran cicilannya dengan tepat waktu dan nasabah yang mengalami penurunan kemampuan pembayaran.

b. Besar potongan sebagaimana dimaksud di atas diserahkan pada kebijakan LKS.

c. Pemberian potongan tidak boleh diperjanjikan dalam akad ${ }^{57}$.

\section{Penyelesaian Piutang Murabahah Bagi Nasabah Tidak Mampu Membayar.}

Ketentuan penyelesaian pokok masalah dalam fatwa tersebut adalah LKS boleh melakukan penyelesaian murabahah bagi nasabah yang tidak bisa menyelesaikan / melunasi pembiayaan sesuai jumlah dan waktu yang telah disepakati dengan ketentuan:

a. Obyek murabahah atau jaminan lainnya dijual oleh nasabah kepada atau melalui LKS dengan harga pasar yang disepakati.

${ }^{56}$ Ibid, Himpunan, h.168-170

${ }^{57}$ Ibid, Himpunan, h.190 
b. Nasabah melunasi sisa utangnya kepada LKS dari hasil penjualan.

c. Apabila hasil penjualan melebihi sisa utang maka LKS mengembalikan sisanya kepada nasabah.

d. Apabila hasil penjualan lebih kecil dari sisa utang maka sisa utang tetap menjadi utang nasabah.

e. Apabila nasabah tidak mampu membayar sisa utangnya, maka LKS dapat membebaskannya ${ }^{58}$.

\section{Penjadwalan Kembali Tagihan Murabahah.}

Ketentuan pokok dalam fatwa tersebut adalah LKS boleh melakukan penjadwalan kembali (rescheduling) tagihan murabahab bagi nasabah yang tidak menyelesaikan / melunasi pembiayannya sesuai jumlah dan waktu yang telah disepakati, dengan ketentuan:

a. Tidak menambah jumlah tagihan yang tersisa.

b. Pembebanan biaya dalam proses penjadwalan kembali adalah biaya riil.

c. Perpanjangan masa pembayaran harus berdasarkan kesepakatan kedua belah pihak ${ }^{59}$.

\section{Konversi Akad Murabahah}

Ketentuan akad tersebut adalah: LKS boleh melakukan konversi dengan membuat akad (membuat akad baru) bagi nasabah yang tidak bisa menyelesaikan/melunasi pembiayaan murabahabnya sesuai jumlah dan waktu yang telah disepakati, tetapi ia masih prospektif dengan ketentuan:

a. Murabahah dihentikan dengan cara. Pertama, obyek murabahah dijual oleh nasabah kepada LKS dengan harga pasar. Kedua nasabah melunasi sisa utangnya kepada LKS dari hasil penjualan. Ketiga, apabila hasil penjualan melebihi sisa utang maka kelebihan itu dapat dijadikan uang muka untuk akad ijarah atau bagian modal dari mudharabah dan musyarakah. Keempat, apabila hasil penjualan lebih kecil dari sisa utang

${ }^{58}$ Ibid, Himpunan, h.353-354

${ }^{59}$ Ibid, Himpunan, h.359 
Konsep Jual Beli dalam Fatwa DSN-MUI

maka sisa utang tetap menjadi utang nasabah yang cara pelunasannya disepakati antara LKS dan nasbah.

b. LKS dan nasabah eks - murababah tersebut dapat membuat akad baru dengan akad: Pertama, ijarah muntabiyyah bit tamlik atas barang tersebut di atas dengan merujuk fatwa DSN no.27. kedua, mudharabah dengan merujuk pada fatwa DSN no.07. ketiga, musyarakah dengan merujuk kepada fatwa no. 08.60

\section{Konsep Jual Beli Dalam Fatwa DSN-MUI}

Ada dua jenis jual beli dalam fatwa DSN-MUI, yaitu jual beli mutlak (uang dengan barang) dan sarf (uang dengan uang). Prosedur jual beli, jenis jual beli, dan tata aturan jual beli berkenaan dengan konsekwensi model pembayaran cicilan pada kasus jual beli barang (jual beli mutlak) dan jual beli mata uang (sarf) dalam keputusan-keputusan fatwa di atas adalah wujud pemikiran hukum yang bersifat praktis aplikatif (ijtihad tathbiqi). Fatwa dihasilkan oleh kerja kelompok dengan menggunakan mekanisme tertentu, melibatkan banyak pihak yang memiliki kompetensi dibidang masing-masing, bahkan tidak terbatas ahli hukum Islam saja, yang mana cara tersebut bisa disebut ijtihad kolektif61. Materi-materi kajian fiqh adalah materi ekonomi Islam menurut Qadri Azizy. Ekonomi Islam sumbernya adalah fiqh mu'amalah bukan ekonomi konvensional. Fatwa memiliki posisi penting dalam membangun performa ekonomi Islam ${ }^{62}$. Hal penting yang harus menemukan wujudnya adalah integritas moral dan ekonomi secara utuh ${ }^{63}$.

Persoalan transaksi antara nasabah pengguna produk lending bank syari'ah dengan bank syari'ah, adalah transaksi modern yang praktiknya tidak seluruhnya sama dengan keterangan nash ataupun pemikiran ulama' zaman dulu. Perbedaan praktik yang pokok ada dua. 1. Penggunaan model pembayaran cicilan pada transaksi bank syari'ah. Model pembayaran jual beli dengan cara cicilan belum ada dalam pemikiran ulama' zaman dulu, lebih H.180-192

${ }^{60}$ Ibid, Himpunan, h.365-366

${ }^{61}$ Nur Kholis Majid, Islam Indonesia, Pustaka Pelajar, 1998, h.12

62 Azizy, Qodri A., 2004, Membangun Fondasi Ekonomi Umat, Yogyakarta, Pustaka Pelajar.

${ }^{63}$ Mahfudh, Sahal, 1994, Fiqh Sosial, Yogyakarta, LKIS. H.165 
lebih dalam nash. 2. Prosedur jual beli melalui lembaga keuangan syari'ah. Pemikiran ulama' zaman dulu belum menyentuh soal lembaga keuangan, dimana lembaga tersebut berfungsi sebagai intermediasi keuangan/pembayaran.

Konsep kepastian harga jual beli barang dalam fatwa DSN-MUI menetapkan tidak ada perubahan harga menjadi lebih mahal, karena sebabsebab apapun, tetapi ia mengadopsi diskon harga dan denda. Model pembayaran cicilan menimbulkan beberapa hal yang harus dipastikan dalam pembayaran jual beli. Ia adalah besarnya cicilan, jangka waktu, dan jatuh tempo cicilan. Hal-hal yang pasti tersebut memungkinkan munculnya persoalan kepastian dalam harga yang disepakati. Problematika muncul manakala hal hal yang dipastikan dalam akad tidak bisa dilaksanakan sepenuhnya oleh nasabah. Adakah penalti, denda, atau penambahan harga atas pengunduran jangka waktu?. Sebaliknya manakala nasabah menyelesaikan kewajiban lebih cepat dari yang disepakati, ada kebijakan apa.

Menurut penulis, konsep kepastian harga murababah adalah upaya menghindari riba dan gharar. Fatwa mengatur transaksi barang dengan uang, bukan uang dengan uang. Pertukaran tersebut harus jelas harganya meskipun dilakukan dengan pembayaran tunda angsuran. Meskipun fatwa memutuskan begitu, masih ada perbedaan pendapat ulama' fiqh soal keuntungan dalam murababah dengan pembayaran tunda ${ }^{64}$. Dalam penentuan harga dalam pembiayaan syari'ah, menggunakan salah satu model dari empat model yaitu Mark-up pricing, target - return pricing, value pricing dan going rate pricing. Cara yang lazim dipakai adalah going rate pricing yaitu menggunakan tingkat suku bunga pasar sebagai rujukan ${ }^{65}$. Hal tersebut penting dalam konsep murabahah pada fatwa DSN-MUI, akan tetapi belum ada fatwa tentang cara mana yang bisa dibenarkan menurut syari'ah. Fenomena diskon dan denda menunjukkan kuatnya pertimbangan mengadopsi pola pasar uang. Solusi Uang denda tidak diperkenankan menjadi penghasilan bank syari'ah dan masuk menjadi dana sosial (shadaqah) adalah upaya menghindari riba dan dhalim. Ia berada diluar

64 Muhammad, 2006, Teknik Perhitungan Bagi Hasil Dan Profit Margin Pada bank Syariah, Yogyakarta, UII Press. H.125

65 Supriyadi, Sugeng, 2007, Teori bagi Hasil Dan Profit Margin, Semarang, makalah Workshop Perbankan Syari'ah. H.13 
Konsep Jual Beli dalam Fatwa DSN-MUI

persoalan utama halalkah tambahan pada jual beli murabahah atas dasar penundaan waktu pembayaran.

Murababah dan jenis jual beli barang lainnya di perbankan syari'ah meliputi jual beli, kesepakatan keuntungan dan kesepakatan pembayaran utang. Ada penggabungan antara murabahab dan qard. Tambahan dalam murabahah tidak diperkenankan atas harga yang disepakati karena sebab pengunduran waktu pelunasan atau lainnya. Ganti rugi dalam jual beli hanya bisa diperkenankan pada kerugian riil materiil, tidak boleh memperhitungkan kerugian yang bersifat kemungkinan ${ }^{66}$. Keputusan larangan ada tambahan untuk kasus rescheduling adalah bentuk penghindaran dhalim. Nasabah kena musibah (force majeur) atau tidak mampu harus diberi keluasan waktu pengembalian utang tanpa ada tambahan. Moralitas dalam fatwa jual beli ada pada dua hal; 1. larangan memberi denda kepada nasabah yang tidak mampu. 2. larangan menambah harga karena penambahan waktu (mundurnya waktu) pembayaran. Keduanya belum menjadi arus utama paradigma bisnis jasa keuangan syari'ah dalam konsep fatwa DSN-MUI tentang jual beli. Arus utamanya masih pada prosedur akad formal yang harus ditegakkan.

Fatwa tentang prosedur jual beli berpegang pada kaidah fiqh bahwa barang yang dijual adalah harus syah milik penjual dan bisa diserah terimakan. Prosedur "rumit" dimana bank syari'ah harus membeli barang dan menjual barang adalah upaya keluar dari transaksi utang ditambah kelebihan (bunga). Transaksi sewa modal berupa uang, menggunakan akad pinjaman (qard) dilarang, karena tambahannya (bunga) diputuskan sebagai riba. Definisi riba yang dipakai adalah tambahan tanpa iwad ${ }^{67}$. Pengunduran waktu dianggap bukan iwadh yang shabih atas tambahan dari pokok utang. Dalam hal jual beli mata uang fatwa berpegang pada aturan fiqh, harus kontan dan sama untuk mata sejenis dan kontan untuk mata uang lain jenis. Hal ini untuk menghindari riba fadl, tambahan atas barang ribawi. Uang dianggap masuk katagori barang ribawi karena menjadi patokan harga.

${ }^{66}$ Himpunan, Loc Cit, h.32-322

${ }^{67}$ Musa, Loc Cit, h. 253 


\section{Kesimpulan}

Konsep jual beli dalam fatwa DSN-MUI mengacu pada formalitas prosedur akad dalam fiqh. Transaksi keuangan dilaksanakan dengan iwadh (ganti) berupa barang yang jelas dan wujud. Ada perubahan tata cara sewa modal (kredit) menjadi tata cara jual beli murabahah, salam dan istishna' dengan penggabungan akad jual beli dan qard (utang) dalam sistem angsuran. Jual beli dalam akad ijarah muntabiyyah bi al-tamlik tidak memiliki ketergantungan dengan akad sewa. Transaksi uang dengan uang (tukar menukar uang) hanya bisa dilakukan dengan kontan dan nominal yang sama. Perbedaan nominal boleh dilakukan hanya untuk pertukaran uang yang beda jenis.

Konsep jual beli dalam fatwa DSN-MUI memberi kejelasan atas persoalan hukum Islam tentang teknis transaksi perbankan syari'ah, yang diakibatkan sistem pembayaran cicilan/angsuran, dengan menghindari empat larangan dalam prinsip hukum Islam (riba, maisir, gharar, dbulmun), meskipun belum bisa menghindari kesan nilai waktu pada uang. Konsep ini belum berhasil menyatukan moral dan hukum dalam menghindari riba, maisir, gharar, dbulmun. Harga jual beli yang telah disepakati tidak boleh diubah menjadi lebih besar, tetapi dibolehkan didiskon dengan tanpa perjanjian sebelumnya, karena tidak boleh ada hubungan sebab akibat antara harga yang disepakati dengan diskon yang bisa diberikan bank syari'ah. Hal pokok yang belum jelas dalam fatwa adalah teknik penentuan keuntungan jual beli, karena belum diatur.

Denda ( $t a^{\prime}$ 'ir ir) berfungsi untuk menjaga kedisiplinan nasabah mampu untuk membayar utangnya, oleh karenanya uang denda tidak diperkenankan menjadi keuntungan bank syariah, karena ia adalah shadaqah. Ganti rugi (ta'widh) hanya boleh atas kerugian materiil, bukan kerugian karena kesempatan keuntungan yang hilang.

Konsep jual beli dalam fatwa DSN-MUI berbeda dengan konsep bunga tetap pada kredit. Keuntungan jual beli diperoleh dari harga jual yang disepakati dan tidak bisa berubah. Bunga pada kredit memungkinkan bertambah manakala waktu pengembalian/pembayaran menjadi lebih lama, dengan sistem denda dan rescheduling (penjadwalan ulang). Perbedaan tersebut karena perubahan sistem bunga menjadi sistem keuntungan jual beli. Ia belum mampu menghapuskan substansi dhulmun dalam penarikan keuntungan atas 
Konsep Jual Beli dalam Fatwa DSN-MUI

modal. Ia baru bisa memastikan keuntungan dan harga yang disepakati tidak berubah, meskipun cara menentukan keuntungannya masih seperti bunga atas modal. 


\section{DAFTAR PUSTAKA}

Abidin, Ibnu, t.th, Radd al-Mukhtar, Juz. 4, Dar al-Fikr.

Antonio, Muhammad Syafi'i, 1999, Bank Syari'ah Wacana Ulama' dan Cendekia, Copyright@muhammad Syafi'i Antonio.

al-Asqalani, t.th, al-Hafidz Ibnu Hajar, Bulugh al-Maram Min Adillati al-Abkam, Semarang, Maktabah Usaha Keluarga.

Azizy, Qodri A., 2004, Membangun Fondasi Ekonomi Umat, Yogyakarta, Pustaka Pelajar.

Barlinti, Yeni Salma, 2010, Kedudukan Fatwa Dewan Syariab Nasional Dalam Sistem Hukum Nasional, Jakarta, Balitbang dan Diklat Kemenag RI.

al-Bukhari, Imam Abi Abdillah Muhammad Ibnu Isma'il Ibnu Ibrahim Ibnu al-Mughirah Ibnu Bardazabat, t.th, Al-Bukhari Masykul Bi Hasyiyah alSanad, Juz. 2, Beirut, Dar al-Fikr.

Consulting, Karim Busines, 2001, Islam Dan PerbankanSyari'ah, Jakarta, Biro Perbankan Syari'ah Bank Indonesia.

Departemen Agama RI, 1989, Al-Qur'an Dan Terjemahnya, Semarang, CV.Toha Putra.

al-Dimasyqi, Imam Taqiyuddin Abu Bakar Bin Muhammad al-Hasini alHashni, t.th., Kifayah al-Ahyar Fi Halli ghayah al-Ikhtishar, Dar Ikhya' alKutub al-Arabiyyah.

Himpunan Fatwa Dewan Syari'ah Nasional, 2006, Jakarta, Dewan Syari'ah Nasional-Majelis Ulama' Indonesia dan Bank Indonesia.

al-Jaziri, Abdurrahman, 2003, al-Figh 'Ala al-Madzabibal-Arba'ah, Juz. 2, Dar al-Taqwa Li al-Thab'I Wa al-Nasyar Wa al-Tauzi'.

Karim, Adiwarman, 2004, Bank Islam Analisis Fiqh dan Keuangan, Jakarta, PT Raja Grafindo Persada.

Keputusan Dewan Syari'ah Nasional Majelis Ulama' Indonesia Nomor 1 Tahun 2001.

Mahfudh, Sahal, 1994, Fiqh Sosial, Yogyakarta, LKIS.

Volume IV/Edisi 1/Mei 2013 
Konsep Jual Beli dalam Fatwa DSN-MUI

Mudzhar, Atho', 1993 Fatwa-Fatwa Majelis Ulama' Indonesia, Jakarta, INIS XVII.

Muhammad, 2006, Teknik Perbitungan Bagi Hasil Dan Profit Margin Pada bank Syariah, Yogyakarta, UII Press.

Mujibatun, Siti, 2005, Landasan Normatif Akad Murabahah Dalam Produk Market Bank Syari'ah, Semarang, Tesis Program Pasca Sarjana IAIN Walisongo.

Musa, Kamil, t.th., Al-Abkam al-Mu'amalah, Mu'assasah al-Risalah.

Rusyd, Ibnu, t.th., Bidayah al-Mujtabid, Juz.3, Beirut, Dar al-Fikr.

Sabiq, Sayyid, 2000, Figh al-Sunnah, Dar al-Fatih.

Saeed, Abdullah, 2003, Islamic Banking And interest A Studi of Riba And Its Contemporary Interpretation, terj. Muhammad Ufuqul Mubin dkk, Bank Islam Dan Bunga, Yogyakarta, Pustaka Pelajar.

Shihab, Quraish, 1993, Membumikan Al-Qur'an, Bandung, Mizan.

Sugiyono, 2005, Memahami Penelitian Kualitatif, Bandung, CV. Alvabeta.

Supriyadi, Sugeng, 2007, Teori bagi Hasil Dan Profit Margin, Semarang, makalah Workshop Perbankan Syariah.

al-Syarafi, Abdul Majid, 1998, Al-Ijtihad al-Jama'i Fi al-Tasyri' al-Islamiyyi, terj. Syamsuddin TU, Ijtihad Kolektif, Jakarta, Pustaka al-Kautsar.

Tsalabi, Muhammad Mustofa, 1964, al-Madkhal Fi Ta'rif al-Fiqh al-Islam Wa Qawa'id al-Milkiyyah Wa al-Uqudiyyah, Mathba'ah Dar al-Ta'rif.

Undang-Undang Nomor 21 Tahun 1998 tentang Perbankan Syari’ah. 